\title{
Morpho-Phonological Patterns of Recent Korean Neologisms
}

\author{
Sang-Cheol Ahn, Kyunney Egorova*
}

\author{
North-Eastern Federal University named after M.K. Ammosov, Yakutsk, Russia \\ * Corresponding author. Email: kiounneil @yandex.ru
}

\begin{abstract}
This paper analyzes the morpho-phonological patterns of recent Korean neologisms used in SNS textmessages. To this end, we use the data appearing in recent newspapers and online dictionaries showing the most recent usages since 2017. During the discussion, we categorize the data into several groups and show the statistical distribution, demonstrating the dominant preference of the acronyms. We also argue that the acronyms can be coined, based not only on syllables but also on consonants including the so-called "zero" consonant $\langle 0\rangle$. We claim that this unique consonantal acronym is possible due to the unique Korean writing system which goes back to the $15^{\text {th }}$ century. Furthermore, the unique graphic characteristics of the Korean writing system is reflected in a new trendy neologism, so called "Yaminjeongeum", creating those words whose orthographic forms look similar to the original words only in shape, without carrying any meaning. Finally, we conclude the paper by claiming that the main tendencies in recent neologisms can be defined as anew bilingualism as the youngsters occasionally code-switch between standard usages and neologisms. This new trend is basically initiated by the school children and teenagers. They enjoy using the newly coined words to highlight homogeneity, i.e., for sense of closeness within a peer group. In some cases, moreover, they also enjoy the vulgarity of slang.
\end{abstract}

Keywords: neologism, coinage, acronym, code-switching, SNS, Yaminjeongeum, Korean writing system

\section{INTRODUCTION}

Neologisms are very common in every language all over the world as they represent the communication trends of the young generation, highlighting homogeneity [1]. Just like the cases of other languages, a lot of new coinages have been made in Modern Korean althoughthey often become the targets of criticism for corrupting the grammatical structure. As claimed in Crystal [1], however, the usages (especially the spelling deformation) do not affect the grammatical structure or communication in the standard language. [Spelling deformation was quantitatively studied in the earlier researches (Grinterand Eldridge [2], Hård af Segerstag [3], Kasesniemi and Rautianen [4], Thurlow and Brown [5], Faulkne and Culwin [6], Tagg [7] etc.).] Therefore, many studies try to account for the new coinages, taking them as a new linguistic trend for the young generation [8-10].

\section{METHODOLOGY}

Investigating the overall structure of the Korean neologisms is, however, not an easy task as the new coined words keep emerging from the dailycommunication of the young people. Moverover,depending on the duration of the time period, the coinage pattern may become different. Considering these fators, we thoroughly analyze the patterns of the Korean neologisms which have been used in SNS text messagesin recent years since 2017. During the discussion, we show how the newly coined words reflect the current trends of language usage among the younger generation. To this end, we categorize the data into several groups and discuss how they represent the current sociolinguistic trends of the young generation. We also show various cases of typical new coinages which reflect the unique Korean writing system, Hangeul.

\section{TRENDS IN NEW COINAGE}

The patterns of language usage among the young people are not only different from those of the older generation, but also quite unique, especially in the area of neologisms. A survey conducted in 2017 by Joongang Ilbo (one of the top 3 newspapers in Korea [11]), for example, made reference to a 'dictionary of 2017 neologisms' which contains 16 newly coined words. These words first appeared in a chatting group, Naver Band, then became 
widespread in social media such as Facebook and Twitter (Joongang Ilbo February 8, 2017 [11]). Shown below are the examples written in Korean. (The Romanized representations shown below each example indicate the Korean pronunciations.)

(1) Representative examples of neologisms in 2017

영고, 팬아저, 취존, 와우내, 마상, 아아, 최애, yeong go, paen a jeo, chwi jon, wa u nae, ma sang a a choe ae

할말하않, 사바사, ㅈ, 비담, 인구론,

hal mal ha anh, sa bas a, in jeong, bi dam, in gu ron,

세젤예, 시강, 커엽, 갓띵작

se jel ye, si gang, keo yeup, kas tting jak

At glance, especially for the older generation or even those in their 30's, these new coinages look quite messy and distracting due to the spelling deformation (i.e., more than simple non-standard spellings) or excessive clipping. With a closer look, however, we can categorize them into several types.

\subsection{Syllabic acronyms}

First of all, the most common type is an acronym in which the initial syllable of each word group is picked up. (We use the official Romanization system imposed by the Korean ministry of culture in 2010.)

(2) 영고 영원히 고통받는

yeong go (사람)

yeongwonhi 'forever' gotong-batneun 'pain' (saram)

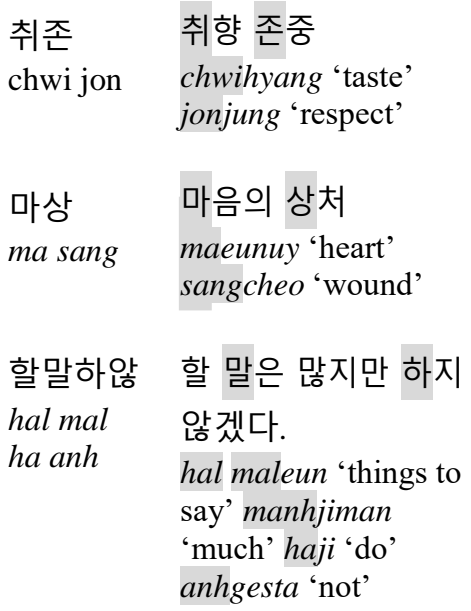

최애최고애(愛, 사랑)

choe ae choego 'best' ae 'love'

인구론 인문계
but wouldn't 'person who suffers from eternal pain'

'respect other's taste'

'wounded heart'

'a lot to say do'

$\begin{array}{ll}\text { 비담 } & \text { 비주얼 담당 } \\ \text { bi dam } & \text { bijueol 'visual' } \\ & \begin{array}{l}\text { damdang 'in } \\ \text { charge' }\end{array}\end{array}$

'the most

Moreover, acronyms can be made by combing English and Korean words as shown in the following examples.

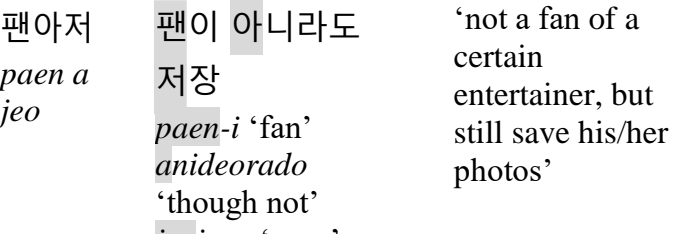

jeojang 'save'

This mixed combination can include common English function words such as "by".
(4)

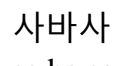
사람 by 사람
sa ba sa
(=사람마다)
saram 'person' bai
'by' saram 'person'
'each to one's own'

Furthermore, only English words can be used to make a "Korean" acronym.
(5) 아아
아이스 아메리카노
aiseu 'ice' amerikano
'Americano'

Similar examples also appeared in this period (Weekly Chosun, September 19, 2017). Many of them are acronyms in which only the initial syllable is picked up from each word block. (The dots indicate syllable boundaries).

(6) More syllabic acronyms

\begin{tabular}{|c|c|c|}
\hline $\begin{array}{l}\text { 낄 끼빠밦 } \\
\text { kkil kki ppa }\end{array}$ & $\begin{array}{l}\text { 낄 때 끼고 빠질 때 } \\
\text { 빠져라 }\end{array}$ & $\begin{array}{l}\text { 'Join when to } \\
\text { join, but quit }\end{array}$ \\
\hline ppa & $\begin{array}{l}\text { kkil ttae kki.go ppa.jil } \\
\text { ttae ppa.jyeo.ra } \\
\text { 'when to join, join' } \\
\text { 'when to quit, quit' }\end{array}$ & when to qu \\
\hline 복붙 & 복사 붙여넣기가 절반 & $\begin{array}{l}\text { 'half of them } \\
\text { are made by }\end{array}$ \\
\hline
\end{tabular}




$\begin{array}{lll}\begin{array}{l}\text { bok.but } \\ \text { (jeol.ban) }\end{array} & \begin{array}{l}\text { bok.sa } \\ \text { but.yeo.neoh.gi.ga } \\ \text { jeol.ban } \\ \text { 'copy' 'paste' 'half' }\end{array} & \begin{array}{l}\text { [copy] and } \\ \text { [paste]' }\end{array} \\ \text { 안물안궁 } & \text { 안 물어봤고 안 궁금해 'didn't ask } \\ \text { an.mul } & \begin{array}{l}\text { an mul.eo bwat.go an and not } \\ \text { an.gung }\end{array} & \begin{array}{l}\text { gung.geum.hae } \\ \text { 'not' 'ask' 'not' }\end{array} \\ & \text { 'curious' }\end{array}$

In 2019, the new coinage processes are similar to those in 2017. First of all, people often use acronyms where the first syllable of each word is picked up. This is the most common type of neologism these days.

(7) Acronyms

$\begin{array}{lll}\begin{array}{l}\text { a. 갑분싸 } \\ \text { gap bun ssa }\end{array} & \begin{array}{l}\text { 갑자기 분위기가 } \\ \text { 싸해짐 } \\ \text { gap.ja.gi bun.wi.gi.ga } \\ \text { ssa.hae.jim } \\ \text { 'suddenly' } \\ \text { 'atmosphere' 'chilly' } \\ \text { suddenly } \\ \text { becomes chilly' }\end{array} \\ \begin{array}{ll}\text { b. 세젤예 } \\ \text { sesang jel }\end{array} & \text { 세상에서 젤(제일) } \\ \text { yeppeun } & \text { 은 } \\ & \text { se.sang.e.seo jel } \\ & \text { ye.ppeun }\end{array}$

Another common type is the combination of Korean word + English word. In some cases, only the first sound ofeach word is collected for combination, e.g., ○ᄀᄅ (이거레알, 이거 레알). 'This is real.' Also, an acronym can be made from an English expression, e.g., TMI. Even a Korean expression can be Romanized before making an acronym from it, i.e., JMT (Jeong.mal Mas.it.Ta) 'really tasty'.

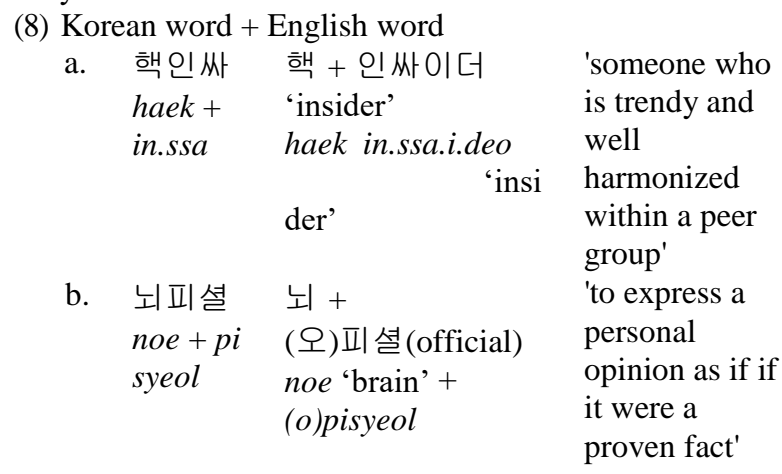

\subsection{Consonantal acronyms}

Many of the acronyms are even simpler, picking up only the initial consonant. The following examples indicate that only the initial consonants can be used to make an acronym.

$$
\begin{array}{ll}
\text { ㅇㅈ전 } & \\
\text { in jeong }
\end{array}
$$

'approval'

$$
\begin{array}{ll}
\text { 그일 } & \text { 이거 }+\quad \text { 'This is real.' } \\
& \text { 레알(real) } \\
& \text { i.geo real } \\
& \text { 'this one' 'real' }
\end{array}
$$

Just like in other many languages like English, Korean youngsters formulate many acronyms which consist of (orthographic) consonants only as shown in the following examples. [The consonantal acronym can be made of English words, e.g., ᄂ ᄂ [n n] (from 노노 'NO NO').] (A

\begin{tabular}{|c|c|c|}
\hline (11) ○下? & $\begin{array}{l}\text { 인정? 응 인정 } \\
\text { Øin.jeong? Øeung }\end{array}$ & $\begin{array}{l}\text { 'accept? } \\
\text { Yes, }\end{array}$ \\
\hline $\begin{array}{l}\varnothing_{\mathrm{j}} \\
\varnothing_{\mathrm{j}}\end{array}$ & Øin.jeong & \\
\hline $\begin{array}{l}\text { ○ } о ~ \\
\varnothing \mathrm{g} \mathrm{r} \varnothing\end{array}$ & $\begin{array}{l}\text { 이거 레알 } \\
\text { Øi geo'this' re.Øal } \\
\text { 'real' }\end{array}$ & $\begin{array}{l}\text { 'This is } \\
\text { real.' }\end{array}$ \\
\hline $\begin{array}{l}\circ \circ\llcorner\circ \\
\varnothing \varnothing \mathrm{n} \varnothing\end{array}$ & $\begin{array}{l}\text { 응 아미야 } \\
\varnothing \text { eung Øa.ni.Øya }\end{array}$ & $\begin{array}{l}\text { 'Yes and } \\
\text { No' }\end{array}$ \\
\hline $\begin{array}{l}\circ \quad \text { o } \\
\varnothing \mathrm{h}\end{array}$ & $\begin{array}{l}\text { 아하 } \\
\varnothing a h a\end{array}$ & 'Ah ha' \\
\hline
\end{tabular}
dot between segments indicates a syllable boundary as the Korean writing system is syllable based.)

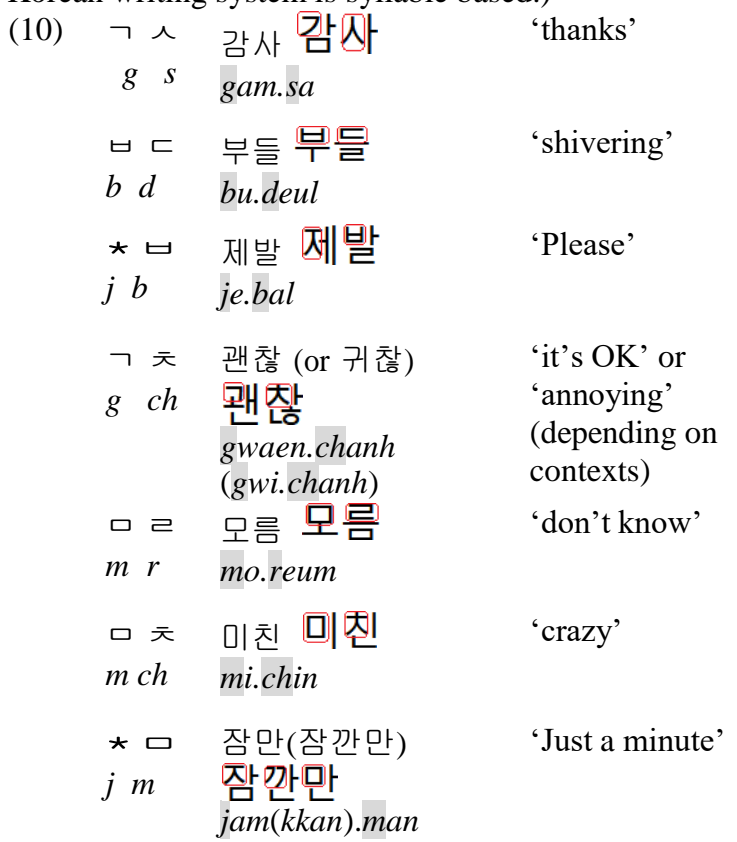

The consonantal acronym can consist of the initial 'zero' consonant which is written as "o" having no phoneticvalue as this zero consonant is only orthographic.

The initial sound of each example is in fact a vowel, but the Korean writing system requires the initial position of syllable should be filled with a consonant orthographically including the zero consonant "o". This tradition goes back 
to the King Sejong period when the Korean alphabet system was invented [12,13]. [In this period, even the final position had to be filled with a zero consonant for a SinoKorean word as there was a distinction between the zero consonant symbol <o> (i.e., phonetically empty) and the one for [y], i.e., $\langle 0\rangle$ (a circle with a horn). Forexample, the name Sejong Eoje "King Sejong made" was written as $<\mathrm{seO}$ jon $\mathrm{O}$ j jeO > (O indicates a zero (i.e., empty) consonant symbol.).]

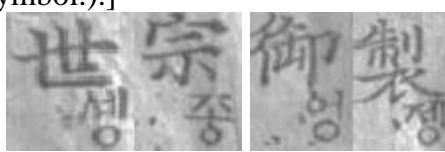

As Modern Korean specifies only the initial zero symbol with a circle, the onset zero symbol is spelled like the coda $/ \mathrm{y} /$. The following example shows the identical transcription of both the onset zero and the final $/ \mathrm{h} /$. Asthe single use of a zero symbol could be confusing in a short, i.e., mono-syllabic word, both circles are used to indicate the zero onset and the nasal coda respectively. That is the "o o" acronym shows that the first "o" indicates a zero consonant, while the second "o' represents $/ \mathrm{y} /$ as they are identical orthographically.

$$
\begin{array}{lll}
\circ & \frac{\text { 응 }}{1} & \text { 'Yes, right' } \\
\varnothing \mathrm{n} & \varnothing \text { eung } &
\end{array}
$$

The coinage by consonantal acronym is extended to those commonly used Romanized expressions. For examples, as both $\circ$ ㄱㄱ (오케이 'Ok') and Ok are commonly used, the

\begin{tabular}{|c|c|c|}
\hline (13) TMI & $\begin{array}{l}\text { Too Much } \\
\text { Information }\end{array}$ & \\
\hline JMT & $\begin{array}{l}\text { Jeong Mal } \\
\underline{\bar{M}} \text { Mas.is.ta } \\
\text { 'really' }\end{array}$ & $\begin{array}{l}\text { (정말 맛있다). } \\
\text { 'really tasty' }\end{array}$ \\
\hline
\end{tabular}
youngsters often use the following Romanized acronyms.

\subsection{Showbiz words, sound symbolic neologisms}

As the influence of the TV show programs is getting stronger for the young generation, a popular expression can be used for new coinage. For example, an entertainer (Park Junhyeong who grew up in the US) with poor Korean proficiency often used "Wow" in a show program, and thus a newly coined word is often used among the young people. [The second examples reflects the modern vowel change by which the two front vowels /e/ $\|$ and $/ \varepsilon / H$ have been being merged. These two vowels are pronounced the same in Modern Korean, especially in the speech of the young people.]

$\begin{array}{ll}\text { (14) 와우내 } & \text { Wow + 내 } \\ \text { wa } u & \text { (misspelled for 네) } \\ \text { nae } & \text { nae 'be' }\end{array}$

On the other hand, just like in the past, some newly-coined expressions are based on the names of the characters in TV advertisements. For example, changryeol-hada 'not worthy

\begin{tabular}{|c|c|}
\hline $\begin{array}{l}\text { 창렬하다 } \\
\text { changryeol-hada }\end{array}$ & $\begin{array}{l}\text { 'not tasty, not worthy' } \\
\text { (Changryeol 'a proper name') }\end{array}$ \\
\hline $\begin{array}{l}\text { ㅖㅖ자스럽다 hyeja- } \\
\text { eu.reop.da }\end{array}$ & $\begin{array}{l}\text { 'tasty, worthy' (Hyeja 'a } \\
\text { proper name') }\end{array}$ \\
\hline
\end{tabular}
or tasty' and hyeja- seureopda 'it is worthy'.

The first expression was named after an entertainer who made a lunch box sold at convenience stores but it was not very tasty. Then, by analogy, the opposite expression was made in reference to another entertainer.

These examples, in fact, originated from the satiric political expressions made in the period of the late Koean president Noh Mu-Hyeon. Early on in his presidency, he had a hot debate with the prosecutors regarding the limit of their powers. As a consequence, the following expressions were made, reflecting the socio-political situation at that period. Similar examples can be made, employing proper names or the names of certain specific professions.

(16) 놈현스럽다nom.hyeon.seu.reop.da ' $\mathrm{He} / \mathrm{she}$ behaves like the president Noh.' Noh Mu-Hyeon 'seem to be' (Nom.hyeon is a contacted form of Noh Mu-Hyeon)

검사그럽다 geom.sa.seu.reop.da 'He/she behaves like a real prosecutor.' 'prosecutor' 'seem to be'

\subsection{Methodolgy of analysis: a statistical analysis}

The biggest Korean online dictionary, Naver open dictionary, posted the 30 most commonly used examples of neologisms in 2019 (Naver open dictionary 2020 [14]). The data collection was based on messages sent on mobile phones and personal computers. Shown below are the 30 examples of new coinages. (The dots indicate syllable boundaries in writing.) 
Table1 Types (A: acronym, F: foreign loanword, S: sound mimicry, T: trendy expression)

\begin{tabular}{|c|c|c|}
\hline $\begin{array}{l}\text { Ranking } \\
\text { /type }\end{array}$ & Words & Meaning \\
\hline 1. F & $\begin{array}{l}\text { 인플루언서 } \\
\text { in.peul.lu.eon.seo }\end{array}$ & 'Influencer', 'person having many followers at SNS' on social networks? \\
\hline 2. A & $\begin{array}{l}\text { 자만추 } \\
\text { ja.man.chu }\end{array}$ & $\begin{array}{l}\text { 자연스러운 만남 추구 } \\
\text { ja.yeon.seu.reo.un man.nam chu.gu } \\
\text { 'seeking unaffected meeting' }\end{array}$ \\
\hline 3. F & $\begin{array}{l}\text { 플렉스 } \\
\text { peul.lek.seu }\end{array}$ & 'Flex, pursy person showing off his/her wealth' (often used in rap music) \\
\hline 4. $\mathrm{A} / \mathrm{F}$ & $\begin{array}{l}\text { 편스토랑 } \\
\text { pyeon.seu.to.rang }\end{array}$ & $\begin{array}{l}\text { 편의점+ 레스토랑 } \\
\text { Pyeon.eui.jeom 'convenience store' + re.seu.to.rang 'restaurant' }\end{array}$ \\
\hline $5 . \mathrm{F}$ & $\begin{array}{l}\text { 무스비 } \\
\text { mu.seu.bi }\end{array}$ & $\begin{array}{l}\text { From the popular expression in a Japanese animation, '무스비(結び. musubi)' } \\
\text { meaning 'destiny' }\end{array}$ \\
\hline 6. F & $\begin{array}{l}\text { 번아웃 증후군 } \\
\text { beon.aut } \\
\text { jeung.hu.gun }\end{array}$ & 'Burnout' + jeung.hu.gun 'syndrome' $\rightarrow$ 'Burnout Syndrome' (exhausted) \\
\hline 7. S & $\begin{array}{c}\text { 버억 } \\
\text { beo.eok }\end{array}$ & $\begin{array}{l}\text { 'ideophonic rejoinder which reflects the sound before eating' (e.g., } \\
\text { chik.chik.phok.phok'chug chug' beo.eok 'so.tteok.so.tteok 'saussage+rice cake' } \\
\text { beo.eok, gimchi.jjige 'kimchi stew' beo.eok, etc.) }\end{array}$ \\
\hline 8. S/F & $\begin{array}{l}\text { 티키타카 } \\
\text { ti.ki.ta.ka }\end{array}$ & $\begin{array}{l}\text { From Spanish tiqui-taca meaning a strategy of a football game using quick short } \\
\text { passes } \\
\text { (Now, it is also used for a situation for amicable quick conversation.) }\end{array}$ \\
\hline 9. A & $\begin{array}{c}\text { 소떡소떡 } \\
\text { so.tteok.so.tteok }\end{array}$ & $\begin{array}{l}\text { 소시지 + 떡 } \\
\text { so.si.ji tteok } \\
\text { 'sausage' 'rice cake' } \\
\text { so.tteok.so.tteok 'saussage+rice cake' (reduplication) }\end{array}$ \\
\hline 10. A & $\begin{array}{c}\text { 처돌이 } \\
\text { cheo.dol.i }\end{array}$ & $\begin{array}{l}\text { cheo-dol(.da) 'get crazy' }+i \text { 'person' } \\
\text { (Originaed from a mascott of chicken café, it often means a person having a mania } \\
\text { for something, e..g, Johnwick.cheo.dol.i 'John Wick mania' or do.thi.cheo.dol.i }\end{array}$ \\
\hline 11. $\mathrm{A} / \mathrm{F}$ & $\begin{array}{l}\text { 스포 } \\
\text { seu.po }\end{array}$ & $\begin{array}{l}\text { Acronym of the game 'Special force' } \\
\text { (e.g., seu.po haja 'Let's play the game 'special force.') } \\
\text { Acronym of '(movie) spoiler' }\end{array}$ \\
\hline
\end{tabular}




\begin{tabular}{|c|c|c|}
\hline & & (e.g., seu.po ha.ji.ma.ra 'Don't tell the overall story of a movie in advance.) \\
\hline 12. A & $\begin{array}{l}\text { 얼죽아 } \\
\text { eol.juk.a }\end{array}$ & $\begin{array}{l}\text { 얼어 죽어도 아이스 } \\
\text { eol.eo juk.eo.do a.i.seu } \\
\text { 'freeze' 'die' 'ice' } \\
\text { 'A person always having cold drinks even in cold weather' }\end{array}$ \\
\hline 13. F & $\begin{array}{l}\text { 까멜리아 } \\
\text { kkamellia }\end{array}$ & 'Name of a store on a KBS drama, i.e., 'camellia' meaning 'waiting, ardent love' \\
\hline 14. S & $\begin{array}{l}\text { 쓰앵님 } \\
\text { sseu.aeng.nim }\end{array}$ & $\begin{array}{l}\text { Ideophonic coinage, reflecting seon.saeng.nim (선생님) 'Mr. Sir'. The popularity } \\
\text { came from a drama in which seon.saeng.nim was pronounced as sseu.aeng.nim. }\end{array}$ \\
\hline 15. A & $\begin{array}{l}\text { 등드름 } \\
\text { deung.deu.reum }\end{array}$ & $\begin{array}{l}\text { 등 + 여드름 } \\
\text { deung 'back' + yeo.deu.reum 'pimple' } \rightarrow \text { 'pimple on one's back', }\end{array}$ \\
\hline 16. F & $\begin{array}{l}\text { 밈 } \\
\text { mim 'meme' }\end{array}$ & $\begin{array}{l}\text { mimeme 'unknown' (Greek) + 'gene' } \\
\text { 'an idea or element of social behaviour passed on through generations in a culture, } \\
\text { especially by imitation' }\end{array}$ \\
\hline 17. A & $\begin{array}{l}\text { 파이어족 } \\
\text { pa.i.eo.jok }\end{array}$ & $\begin{array}{l}\text { 'Fi (Financial Independenc)' + 'Retire Early' + jok 'tribe' } \\
\rightarrow \text { 'People in the } 30 \text { 's or } 40 \text { 's who take early retirement after achieving financial } \\
\text { indenpence' }\end{array}$ \\
\hline 18. A & $\begin{array}{l}\text { 꾸안꾸 } \\
\text { kku.an.kku }\end{array}$ & $\begin{array}{l}\text { 꾸민 듯 안 꾸민 듯 'unclear if makeup is put on or not' } \\
\text { kku.min.deus an kku.min.deus } \\
\text { 'as if using make-up' 'as if not using make-up' }\end{array}$ \\
\hline 19. A & $\begin{array}{l}\text { 만반잘부 } \\
\text { mam.man.jal.bu }\end{array}$ & $\begin{array}{l}\text { 만나서 반가워 잘 부탁해 } \\
\text { man.na.seo ban.ga.weo jal bu.tak.hae } \\
\text { 'meet' 'glad' 'well' 'take care' } \rightarrow \text { 'Nice to meet you' }\end{array}$ \\
\hline 20. T & $\begin{array}{l}\text { 나만없어고양이 } \\
\text { na.mam.eop.seo } \\
\quad \text { go.yang.i }\end{array}$ & $\begin{array}{l}\text { 'Everybody has a cat, except me.' } \\
\text { It represents a person who is envious of those who have cats.' }\end{array}$ \\
\hline 21. A/F & $\begin{array}{l}\text { 유하 } \\
\text { yu.ha }\end{array}$ & $\begin{array}{l}\text { Youtube }+ \text { hi } \\
\text { (It is often used in one-person mass media, e.g., youtube-gam.i.da 'worth being put } \\
\text { on 'Youtube'.) }\end{array}$ \\
\hline 22. A & $\begin{array}{l}\text { 학종 } \\
\text { hak.jong }\end{array}$ & $\begin{array}{l}\text { hak.saeng.bu jong.hap jeon.hyeong } \\
\text { 'school report' 'comprehensive' 'assessment' } \\
\rightarrow \text { a qualitative assessment report for student's overall performance. It is used as an } \\
\text { essential evaluation basis for college entrance exam. }\end{array}$ \\
\hline
\end{tabular}




\begin{tabular}{|c|c|c|}
\hline $23 . \mathrm{F}$ & $\begin{array}{c}\text { 유니콘기업 } \\
\text { yu.ni.kon gi.eop }\end{array}$ & $\begin{array}{l}\text { yu.ni.kon + gi.eop } \\
\text { 'unicorn' 'company' } \\
\rightarrow \text { an unlisted start-up company of which the enterprise value exceeds one billion } \\
\text { dollars. }\end{array}$ \\
\hline 24. A & 존맛탱 & $\begin{array}{l}\text { 존 맛 탱 } \\
\text { 'good' 'taste' 'thing' } \rightarrow \text { 'very tasty' } \\
\text { (A smilar example is 졸귀탱 jol.gwi.taeng 'very cute'.) } \\
\text { It is also often used as a Romanized acronym, i.e., JMT. }\end{array}$ \\
\hline $25 . \mathrm{S}$ & $\begin{array}{l}\text { 라떼는 말이야 } \\
\text { la.tte.neun mal.i.ya }\end{array}$ & $\begin{array}{l}\text { It is a satirical expression of na.ttae.neun mal.i.ya 'when I was (somebody } \\
\text { important)', from which the first part, na.ttae, is changed to la.tte '(café) latte' due } \\
\text { to the similarity in sounds. (An initial liquid is realized as [n] in Korean, so /l/ and } \\
\text { /n/ are pronounced the same. v [This process discouraging initial liquids in Korean } \\
\text { is called 'Initial avoidance'[15]]. The younger generation even go further, making } \\
\text { 'Latte is horse', as the Korean word mal 'a story or situation' and the English word } \\
\text { horse are homophonous in Korean. }\end{array}$ \\
\hline 26. T & 몸신 & $\begin{array}{l}\text { mom 'body' }+\sin \text { 'god' } \\
\text { It means somebody who has succeded in making a healthy body. (It is quite similar } \\
\text { to 몸짱 mom.jjang 'a muscle-bound person.) }\end{array}$ \\
\hline 27. A & 오놀아놈 & $\begin{array}{l}\text { 오(우) 놀 줄 아는 놈인가 } \\
\text { o.u nol jul a.neun nom.in.ga } \\
\text { 'Oh' 'able to play' 'guy' } \\
\text { 'Somebody who knows how to play well' }\end{array}$ \\
\hline $28 . \mathrm{A}$ & 인만추 & $\begin{array}{l}\text { 인위적인 만남을 추구하다 } \\
\text { in.wi.jeok.in man.nam.eul chu.gu.ha.da } \\
\text { 'man-made' 'meeting' 'seek' } \\
\text { It means 'seeking for a meeting which is planned by a third party'. }\end{array}$ \\
\hline 29. T & $\begin{array}{l}\text { 수능금지곡 } \\
\text { su.neung } \\
\text { geum.ji.gok }\end{array}$ & $\begin{array}{l}\text { 수학능력시험 }+ \text { 금지곡 } \\
\text { su.hak.neung.ryeok.si.heom geum.ji.gok } \\
\text { 'Scholastic aptitude test' 'forbidden song' } \\
\text { It means those songs which linger in the head, distracting students' attention while } \\
\text { they are preparing for the SAT or taking an examination. }\end{array}$ \\
\hline 30. T/F? & $\begin{array}{l}\text { 세포마켓 } \\
\text { se.po ma.ket }\end{array}$ & $\begin{array}{l}\text { 세포 se.po 'cell' + 마켓 ma.ket 'market' } \\
\text { It indicates a 'cell market', i.e., a type of marketing which makes use of online }\end{array}$ \\
\hline
\end{tabular}




\begin{tabular}{|l|l|l|}
\hline & $\begin{array}{l}\text { platforms, such as SNS or blogs. They also use the term 'cell sumer' to indicate } \\
\text { those individuals (e.g., instagrammer) who manages cell market' }(<\text { 'pro-sumer' } \\
\text { Albin Toppler) }\end{array}$ \\
\hline
\end{tabular}

As we have already assumed, the most dominant pattern of new coinage is an acronym in which only a part of each word (or phrase) is picked up for combination. In most cases, the intial syllable is chosen for combination.

\section{(17) a.자연스러운 만남 추구 \\ ja.yeon.seu.reo.un man.nam chu.gu \\ 'unaffected' 'meeting' 'seek' 'seeking unaffectedmeeting' \\ b. 인위적인 만남을 추구하다 \\ in.wi.jeok.in man.nam.eul \\ chu.gu.ha.da \\ 'man-made' 'meeting' 'seek' \\ 'seeking a meeting}

which is planned by a third party'.

The first example (17a) means 'seeking an unaffected

meeting'. Contrary to this expression, the younger

generation also use the 인만추 in.man.chu in (17b),

meaning 'seeking for a meeting which is planned by a third party'.

Contrary to these acronyms taking the initial syllables, however, the remaining parts of the second word can be used if the initial syllable cannot convey any meaning. In the following example, for instance, the first syllable of the second word in (18a), yeo, does not mean anything, so they take the rest of the second word. In this case, they take all the remaining parts, i.e., more than one syllable, so that the meaning can be recovered more easily in the new coinage. Taking all the remaining syllables from the second word can be observed in the other example (18b) taking a foreign loanword.

(18) a. 등 + 여드름

$\underline{\text { deung }}$ 'back' + yeo.deu.reum 'pimple' $\rightarrow$ 'pimple on one's back'

b. 편의점+ 레스토랑

Pyeon.eui.jeom 'convenience store' + re.seu.to.rang 'restaurant'
There are many cases of new coinages making use of foreign loanwords. The popularity of foreign (especially English) words can be observed even in sound mimicry.

(19) 라떼는 말이야

la.tte.neun mal.i.ya 'When I was someone....'

It is a satirical expression of na.ttae.neun mal.i.ya 'when I was (somebody important)' which is frequently used by the older generation. It literally means '(When I was young or somebody important), my situation was...' Thefirst part, na.ttae, is changed to la.tte which sounds like the popular drink '(café) latte'. (An initial liquid is realized as [n] in Korean, so $/ \mathrm{l} /$ and $/ \mathrm{n} /$ are pronounced the same. [This process discouraging initial liquids in Korean is called "Initial avoidance'(Ahn 2010).]) This type of pun even produces the expression, 'Latte is horse' as the Korean word mal 'a story or situation' and the English word horse are homophonous in Korean.

The final type of new coinage is the use of trendy expressions, mostly from TV programs, e.g., dramas or talk shows. The following example, for examples, became famous, representing a person who is envious of those who have cats.' It reflects the current social trend in Koreawhere a lot of people have pet cats (or dogs).

\section{(20) 나만 없어고양이}

na.mam.eop.seo go.yang.i 'Everybody has a cat, except me.'

We can also find certain expression reflecting the hotissues the youngsters have to face. For examples, the following case means "earworms", those songs which linger in the head, distracting students' attention while they are preparing SAT or taking examination.

$$
\text { 수학능력시험 }+
$$

\section{금지곡 su.hak.neung.ryeok.si.heom}

geum.ji.gok 'Scholastic aptitude test'

'forbidden song'

The following table shows the categorical distribution of the newly coined expressions, along with the overlapping pattern.

Table 2 Categorical distribution

\begin{tabular}{|c|c|c|c|c|c|}
\hline Types & $\begin{array}{c}\text { Total } \\
\mathbf{( 3 0 )}\end{array}$ & $\begin{array}{c}\text { Overlap with } \\
\text { acronym }\end{array}$ & $\begin{array}{c}\text { overlap with } \\
\text { Foreign word }\end{array}$ & $\begin{array}{c}\text { Overlap with } \\
\text { sound mimicry }\end{array}$ & $\begin{array}{c}\text { Overlap with } \\
\text { trend }\end{array}$ \\
\hline Acronym & 15 & - & 3 & - & 1 \\
\hline Foreign word & 12 & 3 & - & - & - \\
\hline Sound mimic & 4 & - & 1 & - & - \\
\hline Trendy expression & 4 & - & 1 & 1 & - \\
\hline
\end{tabular}


Among the 30 most representative examples of new coinage, we can notice that acronyms make up half of the new coinages, while all the patterns overlap with the new coinage with foreign words. So, taking the overlapping examples into account, we can show the distributional pattern of the new coined expressions as follows, in which the most dominant pattern is the acronym which is followed by the new coinage with foreign words.

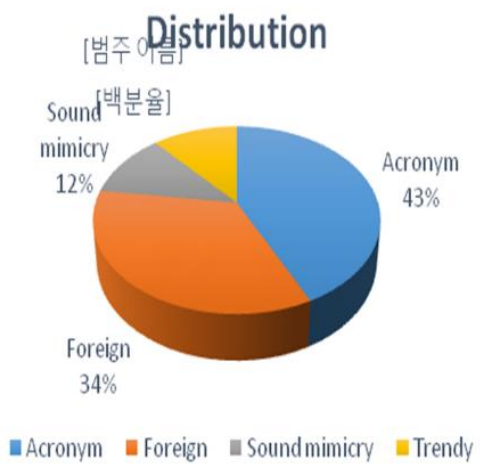

Figure 1 Distributional pattern

The overlapping pattern of each category can be better shown in the following diagram which shows that the 15 acronyms are the most dominant pattern making up $50 \%$, followed by the 12 coinages with foreign words. Although all four categoies overlap with other areas, the usage of foreign words (marked in orange) is observed in all categories, which reflects the preference of the foreign words in the speech of the younger generation.

\section{MEANINGLESS \\ COINAGE \\ FOR ORTHOGRAPHIC \\ SIM}

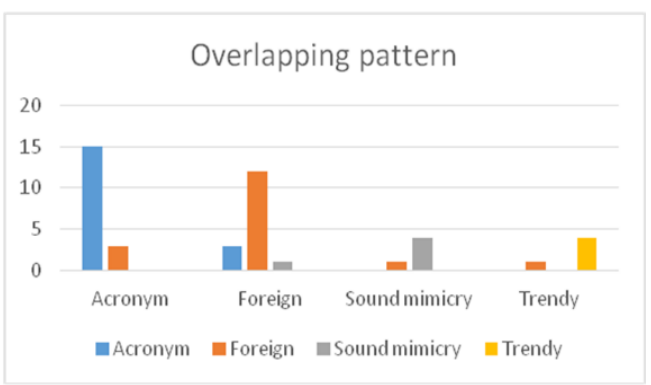

Figure 2 Overlapping pattern

\section{ILARITY: YAMINJEONGUM}

The final two examples in (22) show a very interesting type which is now called Yaminjeongum (야민정음 and 野 民正音 in Korean and Chinese letters). It indicatesa writing method used in internet chatting in which a

certain syllable is written as a different but a similar looking one. For example, 귀엽 (gwi yeop) 'cute' looks similar to the meaningless 커엽 (keo yeop) and 명작 (myeong jak) 'masterpiece' can be misread as 띵작 (tting jak) orthographically. This (humorous) misreading can lead to the acronym to which an English word can be added. (This peculiar process is called Yaminjeongum which will be shown again later.)

$$
\begin{array}{ll}
\text { 커엽 } & \text { 귀엽 'cute' } \\
\text { keo yeop } & \text { gwi yeop } \\
\text { 갓띵작 } & \text { God+띵작 (=명작) 'divine } \\
\text { gat tting } & \text { masterpiece' } \\
\text { jak } & \text { gat 'god' ttingjak (=myeong jak) } \\
& \text { 'masterpiece' }
\end{array}
$$

In addition to these new neologisms in 2017, thefollowing examples are often used as well.

a. 유쾌 'gaiety' $\rightarrow$ 윾쾌

$$
\begin{aligned}
& \text { 명언 'maxim' } \rightarrow \text { 띵언 [16] } \\
& \text { 멍멍이 'doggy' } \rightarrow \text { 댕댕이 [14] }
\end{aligned}
$$

A very popular examples is the 'meaningless' name of a noodle product. The 'meaningless' name <괄도 네넴띤 gwaldo nenemtin> humorously indicates <팔도 비빔면 paldo bibimmyeon 'spicy mixed noodle> based on Yaminjeongum since the orthographic shapes of the former look like the latter in Korean alphabet. [The name of the new word-formation process Yaminjeongum (야민정음) was made by changing the initial word of Hunminjeongum (훈민정음). The Hunminjeongum 'correct sound for teaching people' is a documentdescribing an entirely new and native script for the Korean language. It was made and promulgated to the public by King Sejong the Great in the $15^{\text {th }}$ century.]

\section{b. 팔도 비빔면 $\quad \rightarrow \quad$ 괄도 네넴띤}

pal.do bi.bim.myeon gwal.do.ne.nem.ttin

'8 provinces' 'spicy noodles'? ?

This orthographic similarity/(possible) misreading made this product more popular, so that the company is now using the (meaningless) name (네넴띤) as a new noodle brand (괄도 네넴띤) as shown in the following illustration.

(25) a

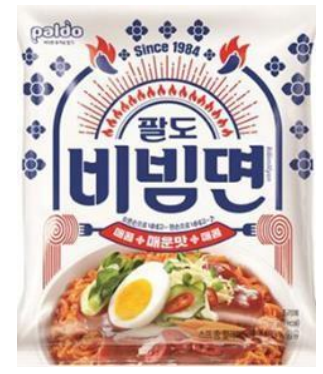

b.

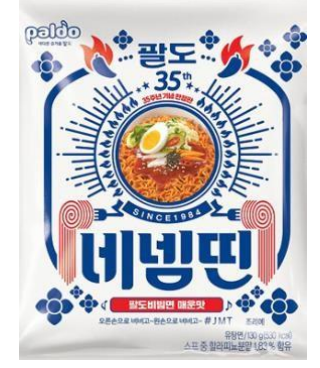


팔도 비빔면

VS. 괄도 네넴띤

(26) New brand from orthographic similarities

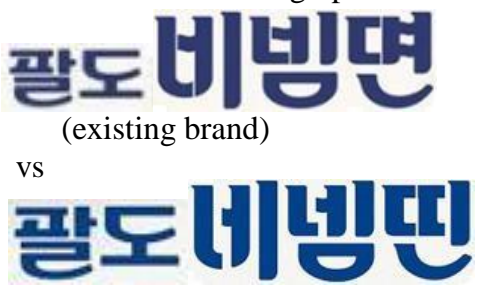

(new brand)

A similar example is the (humorous) RTA noodle as the Korean writing looks like RTA when we look at it upside down.
(27)

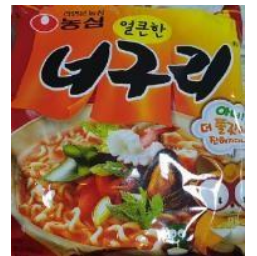

$\rightarrow$

upside down

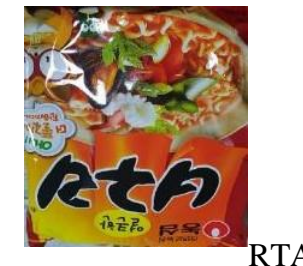

When the product is put upside down, the name (-2) 'racoon' shows like $\mathrm{Cr} / \boldsymbol{C}$ which looks like the Roman letters RTA. Due to this humorous reading, many young people call it RTA noodle and the company has filed an official application for a new brand name (Hyundai Economics Newspaper, August 28, 2019).

The following drink product (in fact, a hangover helper) is also well-known as $I d H$, as this drink product is made of ground pear which is written as which can be misread as $\mathrm{IdH}$. This mispronounced name was also officially licensed as IdH and Idh in 2018 (Hyundai Economics Newspaper, August 28, 2019).

(28)
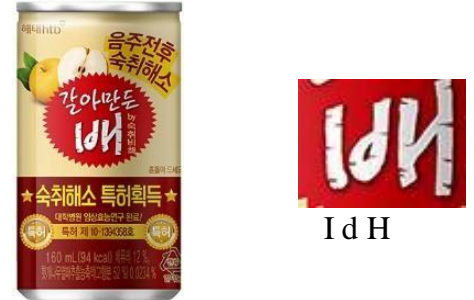

I d H

As English expressions or Roman letters are commonly used in Korea, this type of neologism can be very popular, especially among young people. Also, the neologism in the area of food and drink is very productive as shown in J-S. Lee [8], taking $7.1 \%$ in $2002-2006$ and $5.3 \%$ in 2012-2016.

\section{CONCLUSITON AND FURTHER EXTENSION}

So far, we have discussed the patterns of new neologisms in Korean, based on the recent data collected since 2017. We first categorized the data into several groups in which the acronym is the most preferred type for new coinages. Then, displaying the statistical distribution of the major types of new coinage, we argued for the young people's dominant preference of the acronyms. We also showed that the acronyms can be coined, based not only on syllables but also on consonants including the so-called "zero" consonant $\langle 0\rangle$. We claimed that this unique consonantal acronym is possible due to the unique Korean writing system which goes back to the King Sejong period in the $15^{\text {th }}$ century, requiring all the three CVC slots be filled in orthographically to form a complete syllable in that period. Furthermore, the unique graphic characteristics of the Korean writing system is reflected in a new trendy neologism, so called "Yaminjeongeum", creating those words whose orthographic forms look similar to the original words only in shape, without carrying any meaning.

The main tendancies in recent neologisms can be defined as a new bilingualism as the youngters occasionally codeswitch between the standard usages and neologisms. This new trend is basically initiated by the younger generation, e.g., school children and teen agers. They enjoy using the newly coined words to highlight homoneity, i.e., for sense of closeness within a peer group. In some cases, moreover, they also enjoy the vulgarity of slangs.

(29) 뚝배기 깨다 ttuk.bae.gi kkae.da 'break a ceramic

$$
\begin{aligned}
& \text { pot' ( } \rightarrow \text { 'break a head/skull') } \\
& \text { 옥수수 ok.su.su 'corns' ( } \rightarrow \text { 'teeth') }
\end{aligned}
$$

In these examples, the literal meaning of 뚝배기 ttuk.bae.gi 'a cermic pot' is changed to 'a head', while the second example 옥수수 ok.su.su 'corns' is also metaphorically used as 'teeth'.

This vulgarity has been developed further to the "verbal violence", so-called 패드립 pae.deu.rip, which represents an expression to imply parents, grandpartents, or teachers in a non-ethical way' as $\langle p a e\rangle$ is a contracted form of <pae.ryun> 'immorality'. So, it is a hybrid clipping of Korean + English words, meaning 'non-ethical ad-lip'. Below are some examples of verbal violence.

(30) 느금마 neu.geum.ma 'your mother'

\section{애미 ae.mi 'mother'}

As this verbal violence mostly employs those words indicating "mother", it is often called "a maternal insult" (also referred to as "yo mama" joke). Insults can be based on any negative impression, such as obesity, height, age, race, poverty, stupidity, unattarctiveness, etc. It is a common type of offensive expression, as compared toother types of insults, "your mother" insults are especially likely to incite violence [17].

The usage of verbal violence is now widespread in Korean politics since the current ruling party seized the power in 2017.

(31) 대깨문 dae.kkae.mun 'blind followers of Mun.jae.in (current Korean president)'

dae.ga.ri.ga kkae.jyeo.do mun.jae.in

(literal meaning 'We follow Mun even though our headsget shattered')

달창 dal chang 'blind followers of the president and the ruling party'

dal.bit chang.nyeo 'moon' 'prostitute'

(literal meaning 'prostitute working under the moon') 
틀 딱 teul.ttak' '(hateful) anti-government old activists' 'dentures' 'rattling sound' (literal meaning 'rattling sound of dentures, i.e., oldperson'

Due to the political controversies, these expressions are not listed even in the open dictionary, yet. Nontheless, the tendancy for these political verbal violence is on the rise as the whole society is being divided into two opposing political areas. Being based on the younger generations' innovative coinages, the usage of these expressions are now widespread and are certain to continue for a certain period of time.

\section{REFERENCES}

[1] Crystal David, Txtng, the gr8 db8, Oxford University Press, 2008.

[2] Grinter Rebecca, Margery Fldridge, Y do tngrs luv 2 txt msg?, in: Proceedings of the 7th European Conference on Computer-Supported Cooperative Work, Bonn, Germany, 2001.

[3] Hård af Segerstag Ylva, Use and Adaptation of the Written Language to the Condition of Computermediated Communication, PhD Dissertation, University of Goteborg, 2002.

[4] Kasesniemi Jlja-Liisa, Pirjo Rautianen, Mobile culture of children and teenagers in Finland, in: J.E. Katz, M. Aakhus (Eds.), Perpetual Contact: Mobile Communication, Private Talk, Public Performance, Cambridge University Press, 2002, pp. 170-192.

[5] C. Thurlow, A. Brown, Generation Txt? The sociolinguistics of young people's text-messaging, Discourse Analysis Online 2003, Available at: http://www.

shu.ac.uk/daol/articles/open/2002/003/thurlow2002003 $-01 . h t m l$.

[6] X. Faulkne, F. Culwin, When fingers do the talking: A study of text messages, Interacting with Computers 17 (2005) 167-185.

[7] Tagg Caroline, A Corpus Linguistics Study of SMS Text Messaging, PhD Dissertation, University of Birmingham, 2009.

[8] Lee Jin-Sung, Sociocultural dispositions and changes reflected on neologisms, The Sociolinguistic Journal of Korea 25.4 (2017) 87-117.

[9] Kang Eungyeong, New morphemes and the emergence of the unmarkedness, The Journal of Studies in Language 33.4 (2018) 617-635.

[10] Lee Juhee, Smartphone usage and linguistic characteristics of instant messages: With reference to college students, Studies in Phonetics, Phonology and Morphology 25.2 (2019) 195-228.

[11] Joongang Daily Newspaper, February 8, 2017.

[12] Lee Ki-Moon, Gukeosa Gaeseol (Introduction to the History of Korean Language), Taehaksa, 2000.

[13] Lee Ki-Moon, S. Robert Ramsey, A History of Korean Language, Cambridge University Press, 2011.

[14] Naver Online Dictionary, 2019 inki sinjoeo/hwajeui daneo yeonmal jeongsan (A summary of the most popular new coinages in 2019), 2020.

[15] Ahn Sang-Cheol, Korean Phonology, EAP, 2010.

[16] Urimalsaem Online Dictionary, 2020.

[17] Jeffries Stuart, The mother of all insults, The Guardian, July 12, 2006, Available at: https://www.theguardian.com/football/2006/jul/12/worl dcup2006.sport. 